\title{
Effect of oxandrolone therapy on adult height in Turner syndrome patients treated with growth hormone: a meta-analysis
}

\author{
Nicole M. Sheanon ${ }^{1 *}$ and Philippe F. Backeljauw ${ }^{1,2}$
}

\begin{abstract}
Turner syndrome is a chromosomal abnormality in which there is complete or partial absence of the X chromosome. Turner syndrome effects 1 in every 2000 live births. Short stature is a cardinal feature of Turner Syndrome and the standard treatment is recombinant human growth hormone. When growth hormone is started at an early age a normal adult height can be achieved. With delayed diagnosis young women with Turner Syndrome may not reach a normal height. Adjuvant therapy with oxandrolone is used but there is no consensus on the optimal timing of treatment, the duration of treatment and the long term adverse effects of treatment. The objective of this review and meta-analysis is to examine the effect of oxandrolone on adult height in growth hormone treated Turner syndrome patients. Eligible trials were identified by a literature search using the terms: Turner syndrome, oxandrolone. The search was limited to English language randomized-controlled trials after 1980. Twenty-six articles were reviewed and four were included in the meta-analysis. A random effects model was used to calculate an effect size and confidence interval. The pooled effect size of 2.0759 (95 \% Cl 0.0988 to 4.0529) indicates that oxandrolone has a positive effect on adult height in Turner syndrome when combined with growth hormone therapy. In conclusion, the addition of oxandrolone to growth hormone therapy for treatment of short stature in Turner syndrome improves adult height. Further studies are warranted to investigate if there is a subset of Turner syndrome patients that would benefit most from growth hormone plus oxandrolone therapy, and to determine the optimal timing and duration of such therapy.
\end{abstract}

Keywords: Turner syndrome, Oxandrolone, Growth hormone, Height

\section{Introduction}

Turner syndrome (TS) is defined as the complete or partial absence of the second $\mathrm{X}$ chromosome in a phenotypic female. The most common features of TS are short stature and gonadal failure. Turner syndrome occurs in 1/2000 live female births. Short stature is one of the cardinal findings in TS, due to haploinsufficiency of the SHOX gene (short stature homeobox-containing gene on the $\mathrm{X}$-chromosome). Growth failure can be seen in early childhood and is usually obvious by 4 years of age. Mean adult height of TS patients without growth hormone (GH) therapy is about $21 \mathrm{~cm}$ shorter compared to healthy female adults $[1,2]$. Since 1997, the standard treatment for short stature in TS patients has been recombinant human GH. When GH

\footnotetext{
* Correspondence: Nicole.Sheanon@cchmc.org

'Division of Endocrinology, Cincinnati Children's Hospital Medical Center, 3333 Burnet Ave MLC 7012, Cincinnati, OH 45229, USA

Full list of author information is available at the end of the article
}

therapy is commenced in early childhood, TS girls can achieve adult height within the normal range [3, 4]. With delayed TS diagnosis, adult height achieved will likely be compromised due to the shorter time period available for catch-up growth. In addition, TS patients often have delayed, incomplete, or absent puberty, and the lack of a pubertal growth spurt further contributes to their adult short stature [5].

Oxandrolone, in addition to GH therapy, has been used as a treatment in TS girls diagnosed at a later age. Oxandrolone, a synthetic anabolic steroid and derivative of testosterone, improves growth by acting directly at the growth plate, and by increasing IGF-I concentrations [6-8]. Oxandrolone has been shown to increase height velocity in girls with TS when combined with GH therapy [3]. The long term beneficial effect of oxandrolone on adult height in TS women has been debated due to the small sample size of previous studies, varied results 
in adult height outcomes, and the concern of virilization due to this treatment [8-13]. A recent review paper summarized results of three placebo-controlled, doubleblind, randomized trials investigating the safety and efficacy of oxandrolone in GH-treated girls with TS [14]. The authors concluded that oxandrolone can be used in TS girls who are severely short or have a poor response to GH despite good compliance. They recommend a dose of $0.03-0.05 \mathrm{mg} / \mathrm{kg} /$ day starting at the age $8-10$ years.

The purpose of our meta-analysis was to conduct a comprehensive statistical review of all available data on adult height in TS girls treated with GH plus oxandrolone versus GH therapy alone. The advantages of such a meta-analysis are a larger sample size, larger statistical power, and an improved estimate of the true effect size.

\section{Methods}

A comprehensive literature search was conducted to identify all Randomized Control Trials (RCTs) that investigated adult height in GH-treated TS girls also treated with oxandrolone versus placebo. Relevant trials after 1980 were included. Studies before 1980 were excluded because GH was not introduced until 1985. The following databases were searched using the key words "Oxandrolone" AND "Turner Syndrome": The Cochrane Database, MEDLINE, EMBASE, and PUBMED. The search was limited by language (English), type of subjects (human), date (1980 to present), and type of trial (RCT). The decision to include only RCTs was made in order to improve the validity of the results and to ensure that only highquality studies were used. The database search was repeated several times using the combinations of keywords and MeSH terms are listed in Table 1. Bibliographies of the 26 initial articles were reviewed for other relevant articles.

Participants were children and adolescents with TS. The diagnosis of TS was confirmed by karyotype. All of the studies excluded participants with Y chromosome material in the karyotype. Participants were also excluded if they had additional endocrine or metabolic disorders that could affect statural growth except for treated primary hypothyroidism.

The main intervention was oxandrolone. All participants were also on GH either at the same time and/or for several years prior to oxandrolone. All TS subjects were treated with estrogen to induce puberty if clinically indicated (some participants had spontaneous puberty). We felt that it was acceptable to include these patients as long as estrogen replacement was provided in a physiologic manner. The comparison of interest was: $\mathrm{GH}$ plus oxandrolone versus $\mathrm{GH}$ plus placebo.

The main outcome was growth and included studies which reported adult height, near-adult height, and gain in height. Adult height is the gold standard measure of
Table 1 Keywords and MeSH terms used for literature search

Adolescent

Anabolic Agents/therapeutic use

Androgens/adverse effects

Androgens/therapeutic use

Body Height/Physiology

Child

Double-Blind Method

Female

Final Height

Growth Disorder/drug therapy

Human Growth hormone/adverse effects

Human Growth hormone/therapeutic use

Oxandrolone/therapeutic use

Puberty

Time Factors

Turner Syndrome/drug therapy

Turner's Syndrome/Ullrich-Turner syndrome

the efficacy of GH treatment. At the end of the evaluation of all articles only four studies had adult height data and only three studies reported gain in height.

The quality of the articles was assessed formally using the Jaded scale. All of the included studies received a score of 3 or higher. Studies were excluded if: 1- there was not a $\mathrm{GH}$ alone or GH + placebo group, 2- adult height or nearadult height data were not reported, or 3- the study had a Jaded score of less than three.

Data was extracted by the primary author. The extraction was completed in duplicate to ensure the data was extracted correctly. There were no discrepancies identified between the two different data extractions. The data extracted included: number of total patients, number of patients in each group, dose of therapies (GH, oxandrolone, placebo, and estrogen), length of therapies, initial height, final height, predicted adult height, and adult height gain. Additional data extracted, when available, included karyotype, baseline skeletal age, and mid-parental height.

The principal measure of effect was mean difference as the data was continuous. The primary outcome was adult height. Studies that did not have adult height data were excluded. The secondary outcome was adult height gain. Studies were excluded from the secondary analysis if adult height gain was not reported or if adult height gain could not be calculated from the data provided.

Two different statistical models were used: Fixed Effects model and Random Effects Model. Heterogeneity between studies was assessed using Cochran Q statistic with a $\mathrm{p}$ value of less than or equal to 0.05 indicating significant heterogeneity. Secondary analysis was not indicated as the degree of heterogeneity was not significant. A sensitivity 
analysis was performed by running the Random Effects model using different combinations of the included studies to identify if one study had a greater effect on the results.

\section{Results}

The literature search resulted in 26 articles (see Fig. 1). Upon initial review of the abstracts 9 studies were excluded because the outcome being investigated was not adult height [15-23]. Full-text articles were obtained for the remaining 17 articles. Of these 13 additional articles were excluded because they either involved studies on the same patient cohort reported at different time points [24-30], or the subjects were not all treated with $\mathrm{GH}[7,11]$, or adult height data was not available $[12,13,31]$, or there was no control group for $\mathrm{GH}$ alone or $\mathrm{GH}$ plus placebo [32]. Four articles met criteria and were included in the meta- analysis $[3,33-35]$. Bibliographies of these four selected papers were reviewed for other relevant articles; no additional articles were discovered.

The first study was a double-blind, dose-response investigation in which patients were treated with $\mathrm{GH}$ from baseline either combined with placebo or oxandrolone $(0.03 \mathrm{mg} / \mathrm{kg} / \mathrm{d}$ or $0.06 \mathrm{mg} / \mathrm{kg} /$ day $)$ started at 8 years of age

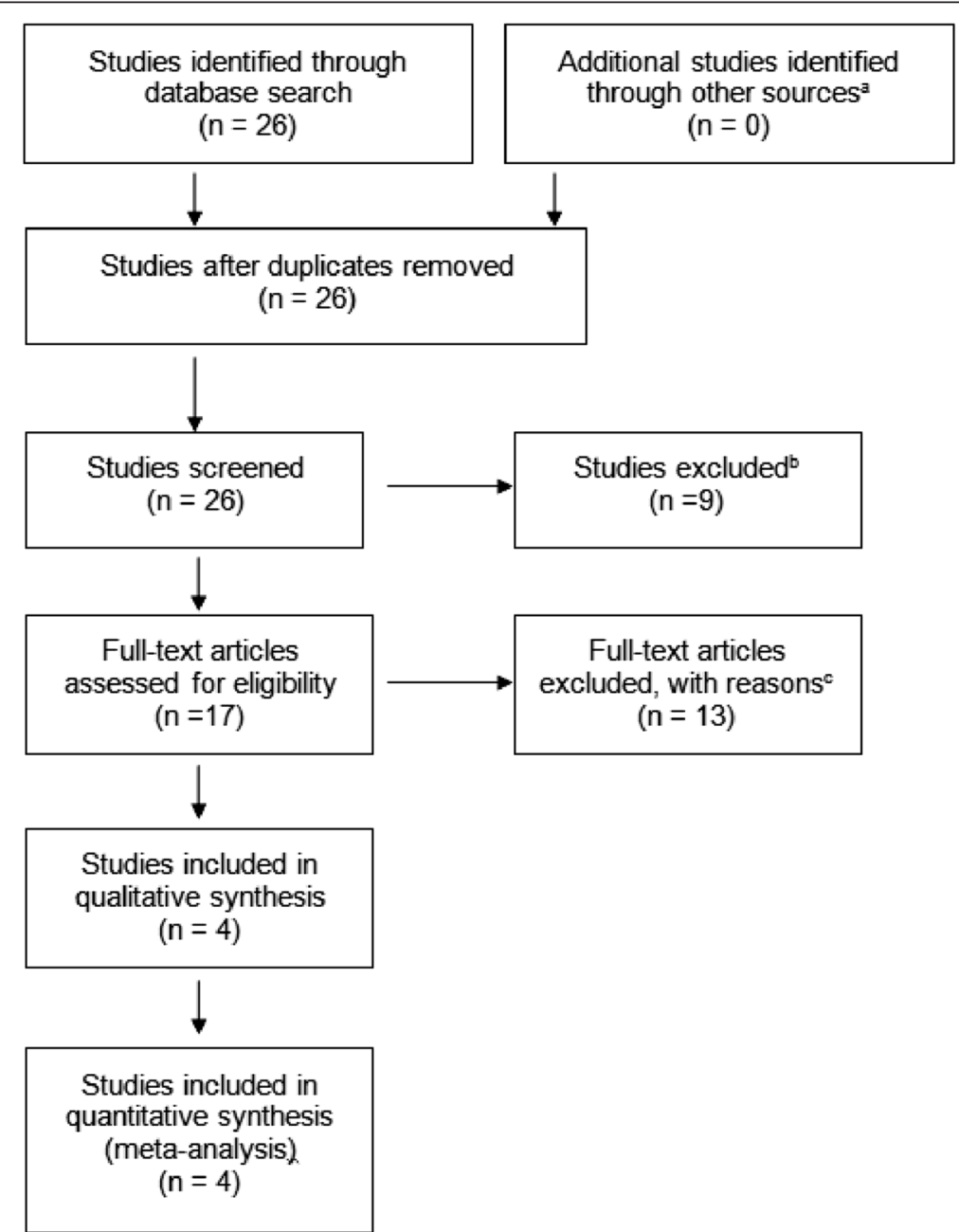

Fig. 1 Flow diagram of article selection. The initial literature search identified 26 articles. Nine articles were excluded because they were not evaluating adult height. An additional 13 articles were excluded because adult height data was not available, not all subjects were treated with growth hormone, or the study included the same cohort as a selected study. ${ }^{a}=$ other sources included asking authors in the field if they were working on any current studies in this area and footnote chasing (looking at references of the 26 articles to identify more articles). ${ }^{b}=9$ studies were excluded because the primary aim was not evaluating final height/near final height, ex. Effect of oxandrolone on glucose metabolism, on voice frequency, on psychological and behavioral characteristics, on body proportions, gonadotropin pulsatility, lipoprotein a, arithmetic learning disability, cognition, and thyroid hormone parameters (reference \# 15-23). ${ }^{c}=13$ studies total were excluded for the following reasons: 3 studies did not have final height or near final height data (ref \#12,13,31), in 2 studies not all subjects were treated with GH (ref \#7, 11), 7 of the studies involved the same cohort/population as the 4 chosen studies (ref \#24-30), and 1 study had no control group on GH only (ref\#32) 
[33]. At 12-13 years of age all the patients were started on estrogen (except those that progressed spontaneously into puberty). A second study was a prospective RCT in which patients who were on $\mathrm{GH}$ were placed on placebo or oxandrolone $0.05 \mathrm{mg} / \mathrm{kg} /$ day (max dose $2.5 \mathrm{mg}$ ) at an average age of 10.2 years and near adult height was obtained [34]. Patients were randomized to receive estrogen at 12 or 14 years of age (except those with spontaneous puberty). Rosenfeld published several RCT studies on the same cohort of patients. The first phase was observation on no medication, oxandrolone alone, GH alone, or oxandrolone $+\mathrm{GH}$. In the second phase the GH-only group continued on GH while the other 3 groups were placed on GH plus oxandrolone. The initial dose of oxandrolone was $0.125 \mathrm{mg} / \mathrm{kg} /$ day but this was decreased after the first year to $0.0625 \mathrm{mg} / \mathrm{kg} /$ day due to virilization. Oxandrolone was started at a mean age of 9.2 years. Estrogen therapy was delayed in all subjects until a chronological age of 14 years. Patients were followed until they reached adult height [3]. The fourth study was also a prospective RCT of patients (average age of 10.3 years) on $\mathrm{GH}$ alone or $\mathrm{GH}$ with oxandrolone $(0.1 \mathrm{mg} / \mathrm{kg} /$ day $)$. Puberty was induced at a mean age of 14.9 years. The patients were followed for 5 years and only 47/91 had reached adult height at time of publication [35]. Individual study results are summarized in Table 2.

Virilization was the main side effect of oxandrolone that was reported. Girls reported voice deepening, hirsutism, and mild clitoromegaly. In the study by Menke the side effects were reported in $5 \%$ of girls on placebo, $16 \%$ of girls on oxandrolone $0.03 \mathrm{mg} / \mathrm{kg} /$ day and in $42 \%$ of girls on oxandrolone $0.06 \mathrm{mg} / \mathrm{kg} / \mathrm{day}$ [33]. Seven subjects on the higher dose and 1 subject on lower dose oxandrolone discontinued treatment due to the virilization effects. In the study by Gault there were no reports of virilization on a dose of $0.05 \mathrm{mg} / \mathrm{kg} /$ day of oxandrolone [34]. Similarly, in the studies by Rosenfeld there were minimal side effects on oxandrolone $0.0625 \mathrm{mg} / \mathrm{kg} / \mathrm{day}$, but the dose was reduced from $0.125 \mathrm{mg} / \mathrm{kg} /$ day after the first year due to $20 \%$ virilization $[3,27]$. In the study by Stahnke there were also reports of virilization (clitoromegaly in 19/44 and deepening of voice in 7/44) but the subjects were on a higher dose of oxandrolone $(0.1 \mathrm{mg} / \mathrm{kg} /$ day $)$. Considering the data together there is a dose-dependent side effect of virilization with minimal effect with doses of oxandrolone less than $0.06 \mathrm{mg} / \mathrm{kg} /$ day.

In each study, for those subjects who did not have spontaneous puberty estrogen was initiated between 12 to 15 years of age. The subjects in the Menke study were started between the age of 12 and 12.99 years on $17-\beta$ Estradiol $5 \mu \mathrm{g} / \mathrm{kg} /$ day orally and increased to $10 \mu \mathrm{g} / \mathrm{kg} / \mathrm{day}$ after 2 years. Cyclic progesterone was added after at least 2 years of estrogen therapy [33]. The subjects in the Gault study received oral ethinylestradiol starting either at age
12 or 14 years in the following manner: year $1,2 \mu \mathrm{g}$; year $2,4 \mu \mathrm{g}$; year 3, four months of each of 6,8 , and $10 \mu \mathrm{g}$. Oral progesterone was started at 15 years of age in all subjects [34]. In the Rosenfeld study estrogen therapy was delayed until a minimum chronological age of 14 years. Oral conjugated estrogens were started at $0.3 \mathrm{mg} /$ day and increased to $0.625 \mathrm{mg} /$ day after 6 months. At 1 year progesterone was added [3]. Finally, in the Stahnke study puberty was induced at a mean age of 14.9 years with estradiol valerate $0.2 \mathrm{mg}$ for the first 6 months and $0.5 \mathrm{mg}$ for the second 6 months. During the second year estradiol was increased to $1 \mathrm{mg}$ and progesterone was started [35]. Each study initiated and titrated estrogen using a slightly different method, but they all used oral estrogens and increased the dose in an incremental fashion in order to simulate natural puberty.

\section{Model results}

The Fixed Effects model (FEM) for adult height yielded a population effect size of $2.0621 \mathrm{~cm}$ with a standard error of 0.6441 and a $95 \%$ confidence interval of $0.01239-4.1118$. The between-study variance was 0.1055. The Random Effects Model (REM) yielded a population effect size of 2.0759 with a standard error of 0.6212 and a $95 \%$ confidence interval of $0.09882-4.0529$. The between-study variance was 1.0900. These results are shown in the Forest Plots in Fig. 2a and b. The effect size for each individual study for adult height and net height gain are listed in Table 3 along with the variance and confidence intervals.

Heterogeneity was assessed using Cochrane's Q. The value was 2.5707 with a $\mathrm{p}$ value of 0.46 (not significant). A secondary analysis was not performed because there was no significant heterogeneity. The lack of heterogeneity implies that the REM can be used because the difference between the FEM and REM is trivial.

Sensitivity analysis was performed by running the REM and eliminating one study each time to assess if one study was contributing more than the others. The effect size for all 4 studies was 2.0759. The effect size after eliminating the Gault et al. study was 2.3325 , after eliminating the Menke et al. study was 2.2966, after eliminating the Rosenfeld et al. study was 2.0950 , and after eliminating the Stahnke et al. study was 1.3501.The effect sizes during the sensitivity analysis indicated that the study by Stahnke et al. [35] may have contributed more to the effect size compared to the other studies.

\section{Discussion}

This is the first and only meta-analysis examining the effect of oxandrolone therapy on adult height in GH-treated TS girls. Our findings suggest that oxandrolone may have a positive effect on adult height and height gain when used in combination with GH. The effect size may have been larger if the studies had been more similar in the 
Table 2 Individual study results. Descriptive data, Mean and standard deviation for adult height and net height gain

\begin{tabular}{|c|c|c|c|c|c|c|c|c|c|c|c|}
\hline Study & $\begin{array}{l}\text { Sample } \\
\text { size }\end{array}$ & $\begin{array}{l}\text { Mean age baseline } \\
\text { yrs (SD) }\end{array}$ & $\begin{array}{l}\text { Mean BA baseline yrs } \\
\text { (SD) }\end{array}$ & $\begin{array}{l}\text { Mean } \\
\text { MPH }\end{array}$ & Intervention & $\begin{array}{l}\text { Dose of Ox } \\
\text { (mg/kg/day) }\end{array}$ & $\begin{array}{l}\text { Mean time } \\
\text { on Ox yrs }\end{array}$ & $\begin{array}{l}\text { Mean AH cm } \\
\text { (SD) }\end{array}$ & $\begin{array}{l}\text { Mean Ht gain } \\
\mathrm{Cm}(\mathrm{SD})\end{array}$ & $\begin{array}{l}\text { Age at estrogen initiation } \\
\text { Yrs (SD) }\end{array}$ & $\begin{array}{l}\text { Puberty } \\
\text { Sp (\%) }\end{array}$ \\
\hline \multirow[t]{3}{*}{ Menke [33] } & 42 & $8.5(4.0)$ & $8.1(3.6)$ & NR & $\mathrm{GH}+\mathrm{Ox}$ & 0.03 & 6 & $156.7(7.2)$ & $9.5(4.7)$ & $12.8(0.9)$ & 21 \\
\hline & 36 & $9.1(3.5)$ & $8.8(3.4)$ & NR & $\mathrm{GH}+\mathrm{Ox}$ & 0.06 & 6 & $156.5(5.8)$ & $8.3(4.7)$ & $12.7(0.9)$ & 24 \\
\hline & 42 & $9.4(3.8)$ & $9.0(3.4)$ & NR & GH + Placebo & & - & $155.6(5.4)$ & $7.2(4)$ & $12.9(1.0)$ & 25 \\
\hline \multirow[t]{2}{*}{ Gault [34] } & 47 & $10.2(1.1)$ & NR & NR & $\mathrm{GH}+\mathrm{Ox}$ & 0.05 & 5 & $151.06(4.53)$ & - & $12(N=12) 14(N=24)$ & 23 \\
\hline & 52 & $10.3(0.9)$ & NR & NR & GH + Placebo & & - & $149.72(6.75)$ & - & $12(N=17) 14(N=28)$ & 13 \\
\hline \multirow{2}{*}{$\begin{array}{l}\text { Rosenfeld } \\
{[3]}\end{array}$} & 45 & $9.9(2.3)$ & 8 & $162.5(4.1)$ & $\mathrm{GH}+\mathrm{Ox}$ & $0.125^{\mathrm{a}}$ & 6 & $152.1(5.9)$ & $10.3(4.7)$ & $14.9(0.9)$ & NR \\
\hline & 17 & $9.1(2.1)$ & 8 & $164.5(3.7)$ & GH + Placebo & & - & $150.4(5.5)$ & $8.4(4.5)$ & $15.2(0.9)$ & $N R$ \\
\hline \multirow[t]{3}{*}{ Stahnke [35] } & 33 & $11.8(2.0)$ & $9.9(1.0)$ & $166.9(4.0)$ & $\mathrm{GH}+\mathrm{Ox}$ & $0.1^{\mathrm{b}}$ & 4 & $155.1(4.5)$ & $7.9(3.8)$ & 14.9 & $N R$ \\
\hline & 38 & $11.7(1.8)$ & $9.9(1.1)$ & $163.6(4.4)$ & $\mathrm{GH}+\mathrm{Ox}$ & $0.1^{c}$ & - & $152.8(3.8)$ & $6.4(3.5)$ & 14.9 & $N R$ \\
\hline & 20 & $11.5(1.2)$ & $10.3(0.5)$ & $165.1(5.5)$ & GH + Placebo & & - & $151.7(3.1)$ & $3.6(2.6)$ & 14.9 & NR \\
\hline
\end{tabular}

AH adult height, $S D$ standard deviation, $O x$ oxandrolone, $H t$ height, $B A$ bone age, $M P H$ mid parental height or target height, $N R$ not reported, $S p$ spontaneous

${ }^{\mathrm{a}}$ Dose cut in half after the first two years of therapy

bDose decreased to $0.05 \mathrm{mg} / \mathrm{kg} /$ day after the first year

transient oxandrolone group, given ox for $<1$ year due to side effects 

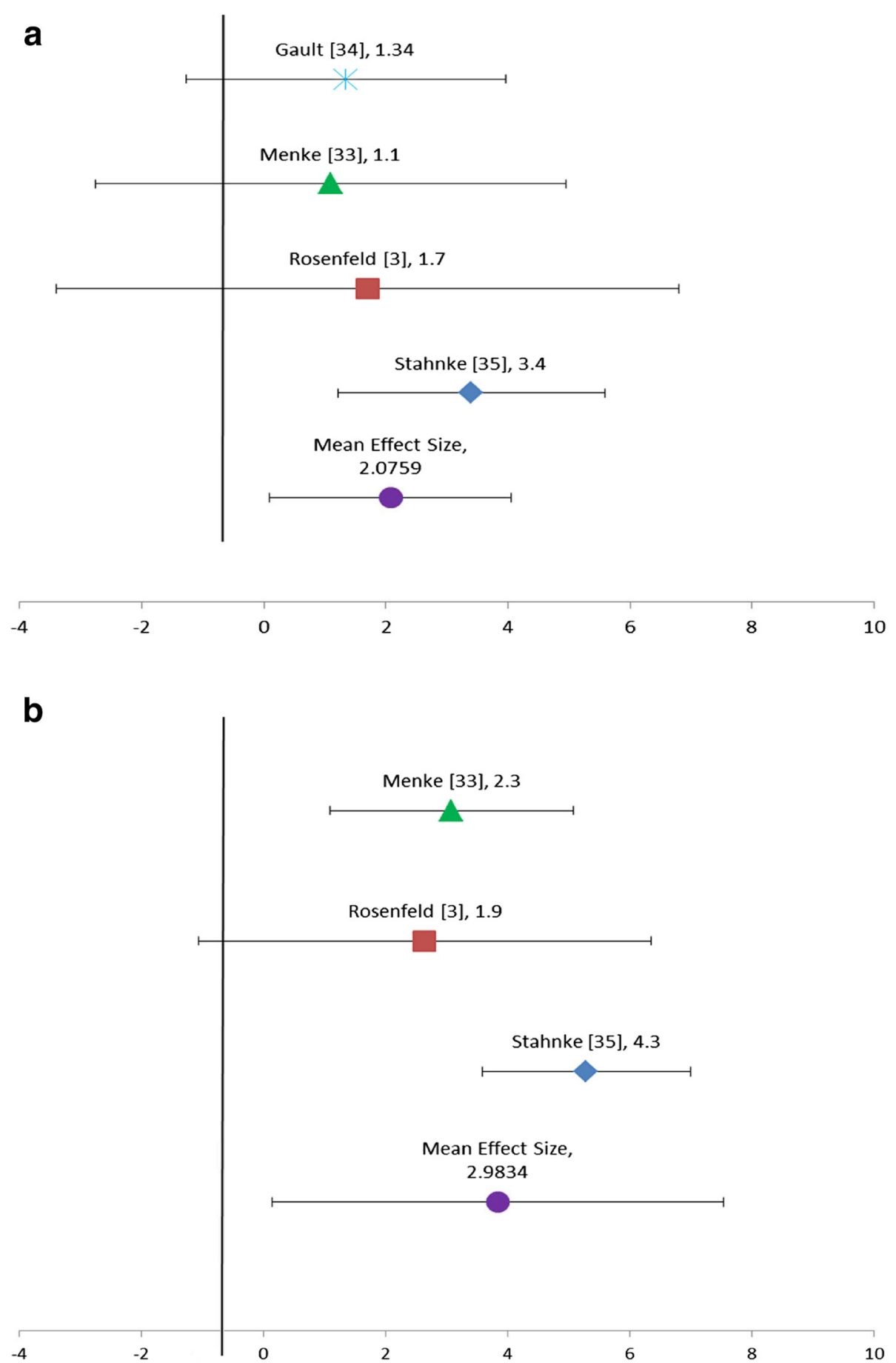

Fig. 2 a Adult height: effect size and $95 \%$ confidence interval. Forest Plot of effect size for each article and mean effect size for adult height. b Height gain: effect size and $95 \%$ confidence interval. Forest Plot of effect size for each article and mean effect size for height gain

additional therapies provided ( $\mathrm{GH}$ and estrogen). However, the lack of heterogeneity found between the studies supports that the differences in dosing and timing of $\mathrm{GH}$ and estrogen may not be significant.

Our meta-analysis supports the conclusions from a recent review by Sas et al. [14]. In that paper, data reviewed from three published randomized, placebo-controlled, double-blind studies (which were also included in our meta-analysis) showed that the addition of oxandrolone to $\mathrm{GH}$ therapy results in an increase in height velocity and yields a modest increase of adult height [13, 33, 34]. The conclusion was that modest doses of oxandrolone 
Table 3 Adult height and height gain effect size, variance, and confidence intervals

\begin{tabular}{lllll}
\hline $\begin{array}{l}\text { Adult height } \\
\text { Study }\end{array}$ & Effect Size & Variance & Upper Cl & Lower Cl \\
\hline Menke [33] & 1.1 & 1.93 & 4.957 & -2.757 \\
Gault [34] & 1.34 & 1.31 & 3.966 & -1.286 \\
Rosenfeld [3] & 1.7 & 2.55 & 6.806 & -3.406 \\
Stahnke [35] & 3.4 & 1.09 & 5.588 & 1.212 \\
Summary & 2.0759 & 0.6212 & 4.0529 & 0.09882 \\
Height Gain & & & & \\
Study & Effect Size & Variance & Upper Cl & Lower Cl \\
\hline Menke [33] & 2.3 & 0.91 & 4.114 & 0.486 \\
Rosenfeld [3] & 1.9 & 1.68 & 5.264 & -1.464 \\
Stahnke [35] & 4.3 & 0.78 & 5.851 & 2.749 \\
Summary & 2.9834 & 0.7796 & 6.3378 & -0.371 \\
\hline
\end{tabular}

(0.03-0.05 mg/kg/day starting from the age of $8-10$ years) were well-tolerated, and that the most important safety issues were enlargement of the clitoris, voice deepening and (temporary) delay of breast development. The authors elected to provide their consensus recommendations after comparing results from three studies only, because of the limited number of wellexecuted studies, differences in oxandrolone doses used, and because of variations in timing of other therapeutic interventions ( $\mathrm{GH}$, estrogens).

The additional strength of our meta-analysis is that the effect sizes for adult height and net height gain were consistent across all studies, indicating that the summary effect size is robust. This can be seen graphically in the Forest plots (Fig. 2a and b). There was moderate discrepancy among the effect sizes in the height gain data, possibly due to the smaller number of studies included. This makes the overall effect size less impactful and the wider confidence interval indicates that this effect size may not be as significant as in the results for the final adult height. The other strength of the meta-analysis is that multiple models were used to analyze the data and the results were similar across all models.

We acknowledge there are some limitations to our metaanalysis approach. There are only four studies included and we may not know the true dispersion of the data. The subjects in each study were on varying doses and duration of GH, which may influence adult height. All of the studies used similar doses of estrogen to induce puberty, but the timing of pubertal induction was different across studies. This is an important point to recognize, because the timing of pubertal induction may affect adult height as well. This limitation was highlighted during the sensitivity analysis: when the Stahnke et al. study was omitted the effect size decreased by 0.7 . In this study, puberty was induced latergiving the subjects more time to grow and they reached a taller adult height. It is unclear if the taller height is due to more time for growth, more time on oxandrolone, or more time on GH. Most likely the taller adult height is a result of a combination of these factors. The other factor which cannot be controlled for is the genetic height potential of the patient. Turner syndrome girls with taller parents are more likely to reach a taller adult height compared to girls who have parents of average height. The final limitation was the inability to include additional studies due to missing adult height data. Specifically the study by Zeger, a randomized, double-blind and placebo controlled study, was not included because the raw mean height data and standard deviation data was not available [13]. In this paper they concluded that "the addition of oxandrolone to $\mathrm{GH}$ at mean age of 12 (1.7) years augmented height gain after 4 years of treatment." Those on oxandrolone grew on average $4 \mathrm{~cm}$ more than those on placebo [13]. The height gain is greater in the Zeger study than in our meta-analysis; this could be due to the high drop-out rate and only near adult height (defined as bone age $\geq 13.5$ years) was assessed. The decision to omit this and other studies was made in order to keep the statistics robust; however, not including these studies could have led to publication bias.

\section{Conclusion}

In conclusion, we provide additional evidence that in short TS girls, in whom severe adult height compromise can be expected, combined treatment of $\mathrm{GH}$ plus oxandrolone should be considered. We concur with the recommendation that treatment can be started around 8-10 years of age and that this should be done at oxandrolone doses ranging between 0.03 and $0.05 \mathrm{mg} / \mathrm{kg} /$ day. Because of the relative paucity of well-executed studies with large enough patient numbers, we suggest that further research still needs to be done to determine the ideal timing of oxandrolone initiation, the duration of treatment with oxandrolone, as well as to better evaluate the long term adverse event profile of this intervention.

\section{Abbreviations \\ TS: Turner syndrome; GH: Growth hormone; RCT: Randomized control trial; FEM: Fixed effects model; REM: Random effects model.}

\section{Competing interests}

The authors declare that they have no competing interests.

\section{Authors' contributions}

NS developed the concept of the proposal under the mentorship of Philippe Backeljauw. NS did the literature search, acquired the data, read the articles and completed the data analysis and interpretation. NS wrote the initial draft of the manuscript and figures, and was involved in the revising and editing the manuscript. PB was involved with the conception of the study. PB was involved with the interpretation of the data and revising and editing the manuscript and figures. Both authors read and approved the final manuscript.

\section{Acknowledgements}

We thank Jeffery Welge, PhD, Research Associate Professor of Psychiatry, for his expertise in meta-analysis and his involvement with design and data analysis. 
Nicole Sheanon, MD was funded by NIH Grant \#5T32DK063929-10 and NIH Grant \#T32ES010957-14 while she was working on this study.

\section{Author details}

'Division of Endocrinology, Cincinnati Children's Hospital Medical Center, 3333 Burnet Ave MLC 7012, Cincinnati, OH 45229, USA. ${ }^{2}$ Department of Pediatrics, University of Cincinnati College of Medicine, Cincinnati, OH, USA.

Received: 5 February 2015 Accepted: 7 July 2015

Published online: 26 August 2015

\section{References}

1. Rongen-Westerlaken C, Corel L, van den Broeck J, Massa G, Karlberg J, Albertsson-Wikland K, et al. Reference values for height, height velocity and weight in Turner's syndrome. Swedish Study Group for GH treatment. Acta Paediatr. 1997;86(9):937-42.

2. Rochiccioli P, David M, Malpuech G, Colle M, Limal JM, Battin J, et al. Study of final height in Turner's syndrome: ethnic and genetic influences. Acta Paediatr. 1994;83(3):305-8.

3. Rosenfeld RG, Attie KM, Frane J, Brasel JA, Burstein S, Cara JF, et al. Growth hormone therapy of Turner's syndrome: beneficial effect on adult height. J Pediatr. 1998;132(2):319-24.

4. Sas TC, de Muinck Keizer-Schrama SM, Stijnen T, Jansen M, Otten BJ, Hoorweg-Nijman JJ, et al. Normalization of height in girls with Turner syndrome after long-term growth hormone treatment: results of a randomized dose-response trial. J Clin Endocrinol Metab. 1999;84(12):4607-12. doi:10.1210/jcem.84.12.6241.

5. Naeraa RW, Nielsen J. Standards for growth and final height in Turner's syndrome. Acta Paediatr Scand. 1990;79(2):182-90.

6. Haeusler G, Schmitt K, Blumel P, Plochl E, Waldhor T, Frisch H. Insulin, insulin-like growth factor-binding protein-1, and sex hormone-binding globulin in patients with Turner's syndrome: course over age in untreated patients and effect of therapy with growth hormone alone and in combination with oxandrolone. J Clin Endocrinol Metab. 1996;81 (2):536-41. doi:10.1210/jcem.81.2.8636264.

7. Haeusler G, Frisch H, Schmitt K, Blumel P, Plochl E, Zachmann M, et al. Treatment of patients with Ullrich-Turner syndrome with conventional doses of growth hormone and the combination with testosterone or oxandrolone: effect on growth, IGF-I and IGFBP-3 concentrations. Eur J Pediatr. 1995;154(6):437-44.

8. Rosenbloom AL, Frias JL. Oxandrolone for growth promotion in Turner syndrome. Am J Dis Child. 1973;125(3):385-7.

9. Moore DC, Tattoni DS, Ruvalcaba RHA, Limbeck GA, Kelley VC. Studies of anabolic steroids .6. Effect of prolonged administration of oxandrolone on growth in children and adolescents with gonadal dysgenesis. J Pediatr. 1977;90(3):462-6. doi:10.1016/50022-3476(77)80717-8.

10. Joss E, Zuppinger K. Oxandrolone in girls with Turner's syndrome. A pair-matched controlled study up to final height. Acta Paediatr Scand. 1984;73(5):674-9.

11. Bareille P, Massarano AA, Stanhope R. Final height outcome in girls with Turner syndrome treated with a combination of low dose oestrogen and oxandrolone. Eur J Pediatr. 1997;156(5):358-62.

12. Rudman D, Goldsmith M, Kutner M, Blackston D. Effect of growth hormone and oxandrolone singly and together on growth rate in girls with X chromosome abnormalities. J Pediatr. 1980;96(1):132-5.

13. Zeger MP, Shah K, Kowal K, Cutler Jr GB, Kushner H, Ross JL. Prospective study confirms oxandrolone-associated improvement in height in growth hormone-treated adolescent girls with Turner syndrome. Horm Res Paediatr. 2011;75(1):38-46. doi:10.1159/000317529.

14. Sas TC, Gault EJ, Bardsley MZ, Menke LA, Freriks K, Perry RJ, et al. Safety and efficacy of oxandrolone in growth hormone-treated girls with Turner syndrome: evidence from recent studies and recommendations for use. Horm Res Paediatr. 2014;81(5):289-97. doi:10.1159/000358195.

15. Menke LA, Sas TC, Stijnen T, Zandwijken GR, de Muinck Keizer-Schrama SM, Otten BJ, et al. Effect of oxandrolone on glucose metabolism in growth hormone-treated girls with Turner syndrome. Horm Res Paediatr. 2011;75(2):115-22. doi:10.1159/000319313.

16. Menke LA, Sas TC, van Koningsbrugge SH, de Ridder MA, Zandwijken GR, Boersma B, et al. The effect of oxandrolone on voice frequency in growth hormone-treated girls with Turner syndrome. J Voice. 2011;25(5):602-10. doi:10.1016/j.jvoice.2010.06.002.
17. Menke LA, Sas TC, Visser M, Kreukels BP, Stijnen T, Zandwijken GR, et al. The effect of the weak androgen oxandrolone on psychological and behavioral characteristics in growth hormone-treated girls with Turner syndrome. Horm Behav. 2010;57(3):297-305. doi:10.1016/j.yhbeh.2009.12.011.

18. Menke LA, Sas TC, Zandwijken GR, de Ridder MA, Stijnen T, de Muinck Keizer-Schrama SM, et al. The effect of oxandrolone on body proportions and body composition in growth hormone-treated girls with Turner syndrome. Clin Endocrinol (Oxf). 2010;73(2):212-9. doi:10.1111/j.1365-2265.2010.03789.x.

19. Nathwani NC, Hindmarsh PC, Massarano AA, Brook CG. Gonadotrophin pulsatility in girls with the Turner syndrome: modulation by exogenous sex steroids. Clin Endocrinol (Oxf). 1998;49(1):107-13.

20. Querfeld U, Dopper S, Gradehand A, Kiencke P, Wahn F, Zeisel HJ. Long-term treatment with growth hormone has no persisting effect on lipoprotein(a) in patients with Turner's syndrome. J Clin Endocrinol Metab. 1999;84(3):967-70. doi:10.1210/jcem.84.3.5516.

21. Ross JL, Mazzocco MM, Kushner H, Kowal K, Cutler Jr GB, Roeltgen D. Effects of treatment with oxandrolone for 4 years on the frequency of severe arithmetic learning disability in girls with Turner syndrome. J Pediatr. 2009;155(5):714-20. doi:10.1016/j.jpeds.2009.05.031.

22. Ross JL, Roeltgen D, Stefanatos GA, Feuillan P, Kushner H, Bondy C, et al. Androgen-responsive aspects of cognition in girls with Turner syndrome. J Clin Endocrinol Metab. 2003;88(1):292-6. doi:10.1210/jc.2002-021000.

23. Schmitt $K$, Hausler $G$, Blumel P, Plochl E, Waldhor T, Frisch $H$. The influence of growth hormone monotherapy and growth hormone in combination with oxandrolone or testosterone on thyroxid hormone parameters and thyroxine binding globulin in patients with Ullrich-Turner syndrome. Eur J Pediatr. 1997;156(2):99-103.

24. Stahnke N, Stubbe P, Keller E. Recombinant human growth hormone and oxandrolone in treatment of short stature in girls with Turner syndrome. Horm Res. 1992;37 Suppl 2:37-46.

25. Rosenfeld RG, Hintz RL, Johanson AJ, Sherman B, Brasel JA, Burstein $S$, et al. Three-year results of a randomized prospective trial of methionyl human growth hormone and oxandrolone in Turner syndrome. J Pediatr. 1988;113(2):393-400.

26. Rosenfeld RG, Hintz RL, Johanson AJ, Sherman B. Results from the first 2 years of a clinical trial with recombinant DNA-derived human growth hormone (somatrem) in Turner's syndrome. Acta Paediatr Scand Suppl. 1987;331:59-69.

27. Rosenfeld RG, Hintz RL, Johanson AJ, Brasel JA, Burstein S, Chernausek SD, et al. Methionyl human growth hormone and oxandrolone in Turner syndrome: preliminary results of a prospective randomized trial. J Pediatr. 1986;109(6):936-43.

28. Rosenfeld RG, Frane J, Attie KM, Brasel JA, Burstein S, Cara JF, et al. Six-year results of a randomized, prospective trial of human growth hormone and oxandrolone in Turner syndrome. J Pediatr. 1992;121(1):49-55.

29. Rosenfeld RG. Acceleration of growth in Turner syndrome patients treated with growth hormone: summary of three-year results. J Endocrinol Invest. 1989;12(8 Suppl 3):49-51.

30. Rosenfeld RG. Non-conventional growth hormone therapy in Turner syndrome: the United States experience. Horm Res. 1990;33(2-4):137-40. discussion 40-2.

31. Job JC, Landier F. Three-year results of treatment with growth hormone, alone or associated with oxandrolone, in girls with Turner syndrome. The Kabi collaborative study group. Horm Res. 1991;35(6):229-33.

32. Nilsson KO, Albertsson-Wikland K, Alm J, Aronson S, Gustafsson J, Hagenas $L$, et al. Improved final height in girls with Turner's syndrome treated with growth hormone and oxandrolone. J Clin Endocrinol Metab. 1996;81(2):635-40. doi:10.1210/jcem.81.2.8636281.

33. Menke LA, Sas TC, de Muinck Keizer-Schrama SM, Zandwijken GR, de Ridder MA, Odink RJ, et al. Efficacy and safety of oxandrolone in growth hormone-treated girls with turner syndrome. J Clin Endocrinol Metab. 2010;95(3):1151-60. doi:10.1210/jc.2009-1821.

34. Gault EJ, Perry RJ, Cole TJ, Casey S, Paterson WF, Hindmarsh PC, et al. Effect of oxandrolone and timing of pubertal induction on final height in Turner's syndrome: randomised, double blind, placebo controlled trial. BMJ. 2011;342:d1980. doi:10.1136/bmj.d1980.

35. Stahnke N, Keller E, Landy H, Serono SG. Favorable final height outcome in girls with Ullrich-Turner syndrome treated with low-dose growth hormone together with oxandrolone despite starting treatment after 10 years of age. J Pediatr Endocrinol Metab. 2002;15(2):129-38. 